\title{
Phytoplankton patchiness in two shallow waterbodies
}

\author{
A. Moñino-Ferrando ${ }^{1}$, E. Moreno-Ostos ${ }^{2, *} \&$ L. Cruz-Pizarro ${ }^{2}$ \\ ${ }^{1}$ Grupo de Puertos y Costas. Centro Andaluz de Medio Ambiente. Avda. Mediterráneo s/n. 18006. Granada. \\ Spain.amonino@ugr.es \\ 2 Instituto del Agua. Universidad de Granada. C/ Ramón y Cajal, 4. 18071. Granada (Spain). enmoreno@ugr.es; \\ lcruz@ugr.es
}

* Corresponding author: enmoreno@ugr.es

\begin{abstract}
Phytoplankton patchiness in two shallow waterbodies

The hydrodynamic behaviour in lentic ecosystems is closely related with the spatial and temporal evolution of their physical, chemical and biological characteristics. Because of this, and in order to improve our present knowledge on the limnological dynamics of such ecosystems, a coupled analysis on the relationship between the biological patterns and the governing hydrodynamics mechanisms it is necessary.

This paper uses both field analysis and numerical simulation to describe the links between the water movements and the phytoplankton spatial distribution on two shallow waterbodies in the South of Spain: Alhama de Granada Reservoir (Granada) and Laguna Nueva de la Albufera de Adra (Almería). In both systems the observed phytoplankton spatial distribution exhibited dynamic patterns forced by hydrodynamical transport processes. The knowledge of this physical-biological coupling could be useful to outline the basic guidelines for water quality management.
\end{abstract}

Key words: Hydrodynamics, phytoplankton patchiness, physical-biological coupling, numerical modelling, lakes, reservoirs.

\section{RESUMEN}

\section{Heterogeneidad espacial del fitoplancton en dos masas de agua someras}

Los ecosistemas acuáticos leníticos se caracterizan por un intenso acoplamiento entre los mecanismos de transporte hidrodinámico que en ellos ocurren y la evolución espacial y temporal de sus principales variables físico-químicas y biológicas. En consecuencia y con el objetivo de mejorar nuestro entendimiento sobre la dinámica limnológica de este tipo de sistemas, resulta necesario el desarrollo de análisis interdisciplinares que profundicen en esta estrecha relación hidrodinámica-biología.

En este trabajo se analiza, a partir de estudios de campo y simulaciones numéricas, el acoplamiento entre el movimiento de la masa fluida a nivel de macroescala y la distribución espacial del fitoplancton en dos ecosistemas acuáticos someros del Sur de España: el embalse de Alhama de Granada (Granada) y la Laguna Nueva de la Albufera de Adra (Almería). En ambos sistemas se han encontrado patrones dinámicos de distribución espacial de las microalgas, íntimamente relacionados con la dinámica de la masa de agua. El conocimiento de este acoplamiento resulta útil en la definición de líneas básicas para la adecuada gestión de la calidad del agua.

Palabras clave: Hidrodinámica, distribución espacial del fitoplancton, acoplamiento físico-biológico, simulación numérica, lagos, embalses.

\section{INTRODUCTION}

In the past, most ecological studies did assume a rather uniform distribution of living organisms in their geographic distribution area. Presently, several ecological models still assume, for simplicity, that biological organisms and their controlling variables are distributed in nature in a ran- 
dom or homogeneous way. As Lengendre \& Fortin (1989) pointed out, this assumption is actually quite remote from reality since the environment is spatially structured by various energy inputs, resulting in patchy structures or gradients. In their study, these authors also conclude that the spatial and temporal heterogeneity of energy inputs induces advection movements in the fluid, leading to the formation of spatial and temporal discontinuities (interfaces) between relatively homogeneous zones. As a consequence, the spacetime structure of the physical environment promotes a similar organization on organisms and biological processes, both in space and time.

The spatial distribution of microalgae in lakes and reservoirs has previously been studied (Heaney, 1976; George \& Heaney, 1978; George \& Edwards, 1976; Petterson et al., 1995; Salonen et al., 1999), always showing complex and heterogeneous spatial patterns, usually related to physical forcing. Harris \& Smith (1977) and Reynolds (1984), among other authors, conclude that, despite early implicit assumptions of the contrary, the presence of phytoplankton patchiness on the horizontal plane of aquatic systems is a more common phenomenon than one would think, and the study of the phytoplankton spatial distribution is, indeed, a main issue in limnological research.

George (1981) showed that the spatial patterns of plankton can be distributed along the complete trophic network, frequently conditioning the nature of the physical and chemical environment. As a result, phytoplankton spatial distribution could greatly influence that of zooplankton, or maybe, some other abiotic factors, such as nutrients concentration or dissolved oxygen. Additionally, spatial heterogeneity has been related to population stability (Steele, 1974).

George (1993) identified three basic types of horizontal plankton patchiness in lakes and reservoirs: 1) Time-dependant small patchiness, coming from a behaviour response of the phytoplankton groups. 2) Advective patchiness, arising from water mass movements induced by external agents. That is the most frequent plankton patchiness in small and medium size lakes and reservoirs. 3) Patchiness generated by reproductive differences between populations under different a)
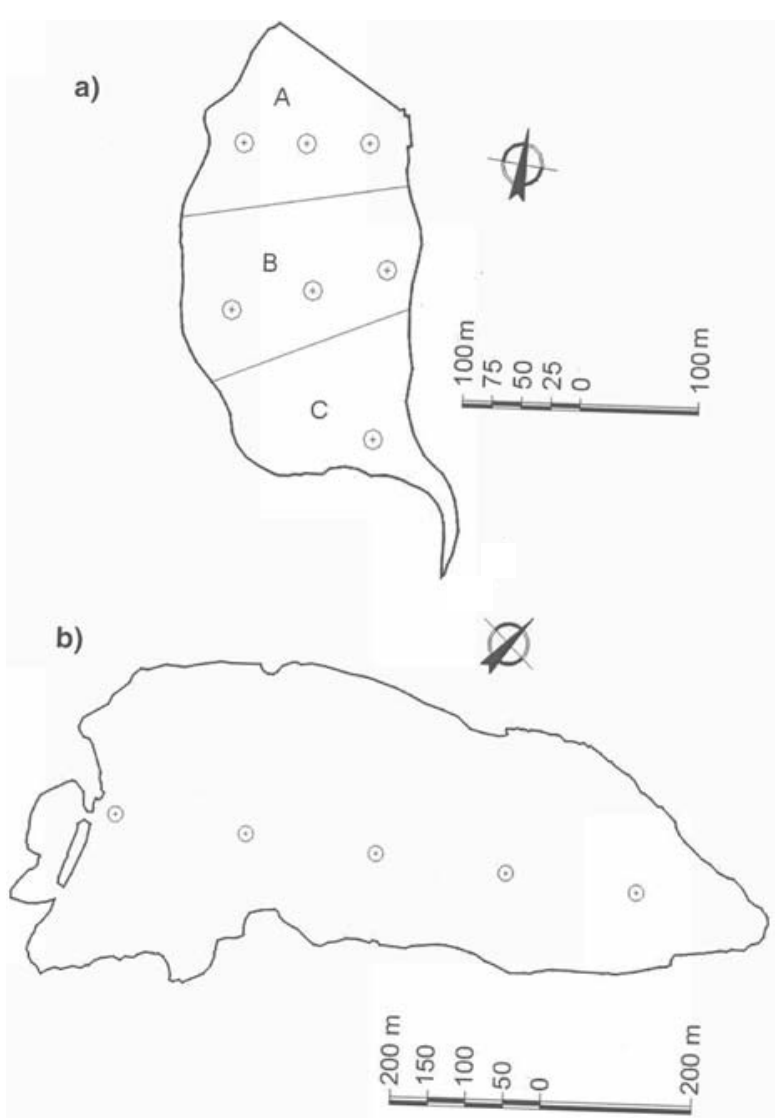

Figure 1. Location of the sampling stations in Alhama de Granada Reservoir (a) and in Laguna Nueva (b). Localización de las estaciones de muestreo en el embalse de Alhama de Granada (a) y en la Laguna Nueva (b).

physical and chemical conditions. This kind of patchiness reaches the maximum space-time extent and is typical of large size aquatic systems.

In a general sense, vertical and horizontal patchiness should come from the spatial heterogeneity of some limiting factors for phytoplankton growth (i.e., local concentration of nutrients) or from water movements induced by the surface wind shear (Verhagen, 1994) that can lead to highly heterogeneous spatial patterns (Legendre \& Demers, 1984). It is, thus, clear that a close relationship should exist between hydrodynamics and phytoplankton patchiness. The role of hydrodynamics in the ecology of waterbodies has been demonstrated in some lakes and reservoirs (Ishikawa et al., 2002; Dubnyak \& Timchenko, 
Table 1. Main limnological features of Alhama de Granada Reservoir and Laguna Nueva. Principales características del embalse de Alhama de Granada y la Laguna Nueva.

\begin{tabular}{cl}
\hline$C$ & Chezy roughness coefficient $\left[\mathrm{m}^{1 / 2} / \mathrm{s}\right]$ \\
$g$ & gravity acceleration $\left[\mathrm{m} / \mathrm{s}^{2}\right]$ \\
$t$ & time variable [s] \\
$U$ & deep-averaged water velocity, horizontal component in the $x$ direction $[\mathrm{m} / \mathrm{s}]$ \\
$U_{W}$ & averaged wind velocity, horizontal component in the $x$ direction $[\mathrm{m} / \mathrm{s}]$ \\
$V$ & deep-averaged water velocity, horizontal component in the $y$ direction $[\mathrm{m} / \mathrm{s}]$ \\
$V_{W}$ & averaged wind velocity, horizontal component in the $y$ direction $[\mathrm{m} / \mathrm{s}]$ \\
$x$ & spatial component in the main fetch direction, horizontal plane $[\mathrm{m}]$ \\
$y$ & spatial component normal to the main fetch direction, horizontal plane $[\mathrm{m}]$ \\
$Z$ & water surface elevation, measured from a reference level $[\mathrm{m}]$ \\
$\rho$ & water density $\left(1000 \mathrm{Kg} / \mathrm{m}^{3}\right)$ \\
$\rho_{A}$ & air density $\left(1225 \mathrm{Kg} / \mathrm{m}^{3}, T=15{ }^{\circ} \mathrm{C}\right.$, at sea level) \\
$\tau_{B x}$ & bottom shear stress in the $x$ direction $\left[\mathrm{Kg} / \mathrm{ms}^{1 / 2}\right]$ \\
$\tau_{B y}$ & bottom shear stress in the $y$ direction $\left[\mathrm{Kg} / \mathrm{ms}^{1 / 2}\right]$ \\
$\tau_{W x}$ & surface wind shear stress in the $x$ direction $\left[\mathrm{Kg} / \mathrm{ms}^{1 / 2}\right]$ \\
$\tau_{W y}$ & surface wind shear stress in the $y$ direction $\left[\mathrm{Kg} / \mathrm{ms}^{1 / 2}\right]$ \\
$v_{T}$ & eddy viscosity $\left[\mathrm{m}^{2} / \mathrm{s}\right]$ \\
\hline
\end{tabular}

2000; George \& Edwards, 1976; George \& Heaney, 1978; George \& Cruz-Pizarro, 1994).

In this paper, a numerical hydrodynamic model has been used for the description of hydrodynamics behaviour and its coupling with the observed phytoplankton spatial distribution. This methodology could constitute a feasible tool in water quality assessment and management, especially useful in the case of reservoirs.

\section{STUDY SITES}

Our study focuses on two Mediterranean aquatic systems: Alhama de Granada Reservoir and Laguna Nueva de la Albufera de Adra (Fig. 1a and $b$, respectively), both located in the South of Spain. The selection of these systems has been based upon the following common characteristics: their shallowness promotes a mixed layer extending from surface to the bottom under the influence of inlet/outlet discharge or surface wind stress. Additionally, those small-sized systems allow development of a synoptic analysis of phytoplankton spatial distribution, as no significant delay stands between measurements from one sampling station to the next.
Wind stress appears to be the first factor determining the hydrodynamic evolution of Laguna Nueva (totally exposed to the prevailing winds). On the contrary, Alhama de Granada is located in an area of mid-height hills, well protected from wind action.

Alhama de Granada was designed as a derivation reservoir, with a diversion tunnel 7 $\mathrm{km}$ long, ending at the neighbour Bermejales reservoir. This last reservoir regulates the adjacent River Cacin basin. Alhama dam works as a flood regulator, ensuring that the water discharge through the diversion tunnel does not exceed a threshold value $\left(30 \mathrm{~m}^{3} / \mathrm{s}\right)$. Alhama de Granada reservoir storage volume has been dramatically reduced due to sedimentation and silting processes.

Laguna Nueva is a natural coastal lagoon, developed during the last century as a consequence of coastal dynamics. Its ecological importance as a wetland inside a semiarid region was in the origin of its legal protection status as Natural Reserve in 1989 and, in 1994, it was included in the list of Protected Areas of the Ramsar Convention (de Vicente et al., 2003).

Table 1 summarises some of the main general features of both water bodies. 


\section{MATERIAL AND METHODS}

\section{Biological determinations}

Chlorophyll- $a$ concentration (Chl- $a ; \mathrm{mg} / \mathrm{m}^{3}$ ) has been used as a suitable surrogate for phytoplankton biomass. The spatial distribution of phytoplankton was detected following straight sampling transects, along which Chl-a concentration was measured in situ or spectrophotometrically determined later on.

\section{Alhama de Granada Reservoir}

Three different sectors have been established in this reservoir, each one having its own bathymetric, ecological and hydrodynamic features (Fig. 1a): the lacustrine zone (A), the transitional zone (B) and the riverine zone (C). A sediment bar in zone $\mathrm{C}$ remains emerged when the water surface level is low enough, as it will be explained further below.

In each zone of the reservoir three sampling stations were established, except for zone C, where a single station was considered because the presence of vegetation makes difficult to reach adjacent measuring locations.

Due to the high concentration of suspended solids (El Mabrouki et al., 2001) spectrophotometric analysis was chosen as a suitable technique to measure Chl- $a$. From each sampling station water samples were collected in black bottles and stored in a dark and cold environment. Once in the laboratory, a known sample volume was filtered through a Whatman GF/C filter $(0.7 \mu \mathrm{m}$ pore diameter), Chlorophyll- $a$ extracted in acetone for 24 hours and its concentration determined by spectrophotometric absorbance following Jeffrey \& Humphrey (1975).

Horizontal phytoplankton patchiness at surface and bottom layers was studied under different hydrodynamic behaviour: the behaviour that might be considered as a normal situation, defined as a set of conditions such as diversion tunnel working, low water level and emerged sediment bar, and another scenario characterised by discharge over the spillway crest $(0.01-0.1 \mathrm{~m}$ water head), diversion tunnel closed, high water level and submerged sediment bar.

\section{Laguna Nueva de la Albufera de Adra}

In this system, a straight transect along the main fetch of the lagoon was considered (Fig. 1b). Five sampling stations were located along this transect, all of them pelagic. Because of a suspended solids concentration lower than in Alhama de Granada (de Vicente et al., 2003) spectrofluorometry in vivo (bbe Fluoroprobe, Moldaenke) was chosen as an accurate methodology for the fast in situ measurement of Chl- $a$ concentration (Beutler et al., 2002; Leboulanger et al., 2002). This technique minimizes the time and optimises the synoptic evaluation, which is totally justified for the system scale.

The Chl- $a$ concentration was measured at each sampling station for three different depths (surface, mid-depth and bottom) to describe both the vertical and horizontal distribution of phytoplankton.

Although two different methods, not equally accurate, were used to determine Chl- $a$ concentration at the different study sites (spectrophotometry and spectrofluorometry) some methodological analysis (Moreno-Ostos, 2002; Moreno-Ostos, 2004) have revealed notorious agreement in their obtained results, so trend comparision can be considered.

In both systems, wind velocity and wind direction were measured in situ at each sampling station, using a field anemometer (AnemoWindmesser) and a compass.

\section{Hydrodynamics and numerical simulation}

Evaluation of water movements and associated velocity fields was carried out both with field data and a numerical model. Field measures were obtained by topographic detection of the spatial and temporal variations at positions defined by various (10) drogues dropped at several characteristic points in the systems at $1 \mathrm{~m}$ depth. This technique yielded the U.T.M. coordinates of the drogues, describing the trajectories and mean velocities of the water currents under different hydrodynamic conditions. All the experiments were carried out under the influence of constant winds, 
Table 2. Symbols used in the text and their definitions. Símbolos utilizados en el texto y su definición.

\begin{tabular}{lcc}
\hline & $\begin{array}{c}\text { Alhama de Granada } \\
\text { reservoir }\end{array}$ & $\begin{array}{c}\text { Laguna } \\
\text { Nueva }\end{array}$ \\
\hline Surface Area & 55 & 272 \\
$\left(10^{3} \mathrm{~m}^{2}\right)$ & 81.5 & 627 \\
Volume $\left(10^{3} \mathrm{~m}^{3}\right)$ & 1.3 & 2.32 \\
Mean depth $(\mathrm{m})$ & 2 & 3.8 \\
Maximum depth $(\mathrm{m})$ & & \\
Annual mean Chlorophyll $a$ & 3.5 & 54 \\
$\left(\mathrm{mg} / \mathrm{m}^{3}\right)$ & 350 & 930 \\
Fetch $(\mathrm{m})$ & &
\end{tabular}

both in speed and direction. Table 2 summarizes the symbols used in the next equations.

With respect to the numerical simulation, the Navier-Stokes-Reynolds equations, verticallyaveraged and simplified using shallow water hypothesis, where solved using the Finite Difference Method. The equations can be written in the following way:

$$
\begin{aligned}
& \frac{\partial U}{\partial t}+U \frac{\partial U}{\partial x}+V \frac{\partial U}{\partial y}=-g \frac{\partial Z}{\partial x}+v_{T} \\
& {\left[\frac{\partial^{2} U}{\partial x^{2}}+\frac{\partial^{2} U}{\partial y^{2}}\right]-\frac{1}{\rho} \tau_{B x}+\frac{1}{\rho} \tau_{W x}} \\
& \frac{\partial V}{\partial t}+U \frac{\partial V}{\partial x}+V \frac{\partial V}{\partial y}=-g \frac{\partial Z}{\partial y}+v_{T} \\
& {\left[\frac{\partial^{2} V}{\partial x^{2}}+\frac{\partial^{2} V}{\partial y^{2}}\right]-\frac{1}{\rho} \tau_{B y}+\frac{1}{\rho} \tau_{W y}}
\end{aligned}
$$

where $U$ and $V$ are the vertically-averaged velocity components, $Z$ is the piezometric line position $\left(Z=z_{B}+h\right.$, where $z_{B}$ is the bed elevation over the reference level and $h$ is the water depth), $v_{T}$ is the eddy viscosity, $\tau_{B}$ is the bottom shear stress and $\tau_{W}$ is the wind shear at the free surface, both in $x$ and $y$-directions (horizontal plane). Equations (1) and (2) correspond to a zero-equation model regarding the closure scheme for the turbulence model (Rodi, 1980). Hence, the turbulent stresses are related to the mean velocity gradient through the eddy viscosity coefficient, which plays a role similar to the molecular viscosity in the case of viscous stresses:

$$
\tau_{T} \approx v_{T} \frac{\partial U}{\partial z}
$$

The left-hand side of equations (1) and (2) corresponds to the Eulerian derivative of the velocity component. On the right-hand, the different terms contain the influence of piezometric line variations on the water movement, turbulent mixing in the horizontal plane (using Boussinesq simplification), bottom shear stress and wind action, respectively. The bottom shear stress is expressed by:

$$
\begin{aligned}
& \tau_{B x}=\rho g \frac{U \sqrt{U^{2}+V^{2}}}{C^{2}} \\
& \tau_{B y}=\rho g \frac{V \sqrt{U^{2}+V^{2}}}{C^{2}}
\end{aligned}
$$

representing the bottom friction in the $x$ and $y$ directions. For the wind shear in the $x$ and $y$ directions, we have:

$$
\begin{aligned}
& \tau_{W x}=c_{W} \frac{\rho_{A}}{\rho}\left(U_{W}-U\right)^{2} \\
& \tau_{W y}=c_{W} \frac{\rho_{A}}{\rho}\left(V_{W}-V\right)^{2}
\end{aligned}
$$

where $C$ is the Chezy coefficient.

For the numerical solution, a value of $C=$ $45 \mathrm{~m}^{1 / 2} / \mathrm{s}$ (a standard value for beaches and coastal platforms of intermediate roughness, that is, mud and sand) was used. The eddy viscosity parameter has to be adjusted during the calculating process in order to obtain an adequate convergence of the model. In the present case, a value of $v_{T} \approx 20.0 \mathrm{~m}^{2} / \mathrm{s}$ was adopted. The deduction of the above equations was omitted to preserve space, but details can be found in several works from different authors (Kundu, 1990; van Rijn, 1990). Shallow water assumption is suitable for the studied systems, since both of them show low depth in relation to the main flux directions (Table 1).

The solutions for the vertically averaged equations of motion provide with the two components of the horizontal velocity field. 
Once the shallow water approximation has been performed, no significant loss of generality for the solutions is expected, since dynamic conditions for the studied systems exhibited slow water movements with no acceleration in the $z$-direction, preserving their uniformity from surface to bottom layers. In other words, horizontal components of the velocity field did not show dependence on the vertical position.

The solutions of the Navier-Stokes-Reynolds equations were devised by using the finite difference model H2DquickWin applied to a centred staggered grid with double-time step. The model also accounts for the wind action, included in the case of Laguna Nueva, as this is the starting mechanism for water movements in that system.

With an adequate calibration of the numerical model based on field data, it is possible to justify the described phytoplankton spatial distribution from the scope of hydrodynamics. Moreover, the numerical model might be reliable enough to simulate different hydrodynamic patterns, i.e. varying the flow discharge or the wind action cha- racteristics, in order to estimate the phytoplankton response. This application results in a suitable tool for phytoplankton management in aquatic ecosystems.

The described biological and hydrodynamic surveys were undertaken in the two studied water bodies every 15 days during March, April and May 2001, covering a wide range of physical scenarios. In situ measurements and sampling took no more than 5 minutes in each sampling station and the travelling time between stations was also around 5-10 minutes. Wind speed and direction were reasonably constant during the whole experiment in both waterbodies.

\section{RESULTS AND DISCUSSION}

\section{Ecohydrodynamics of Alhama de Granada}

In this reservoir we studied the phytoplankton spatial distribution for two different hydrodynamic conditions (Fig. 2): The first one (Fig. 2a)
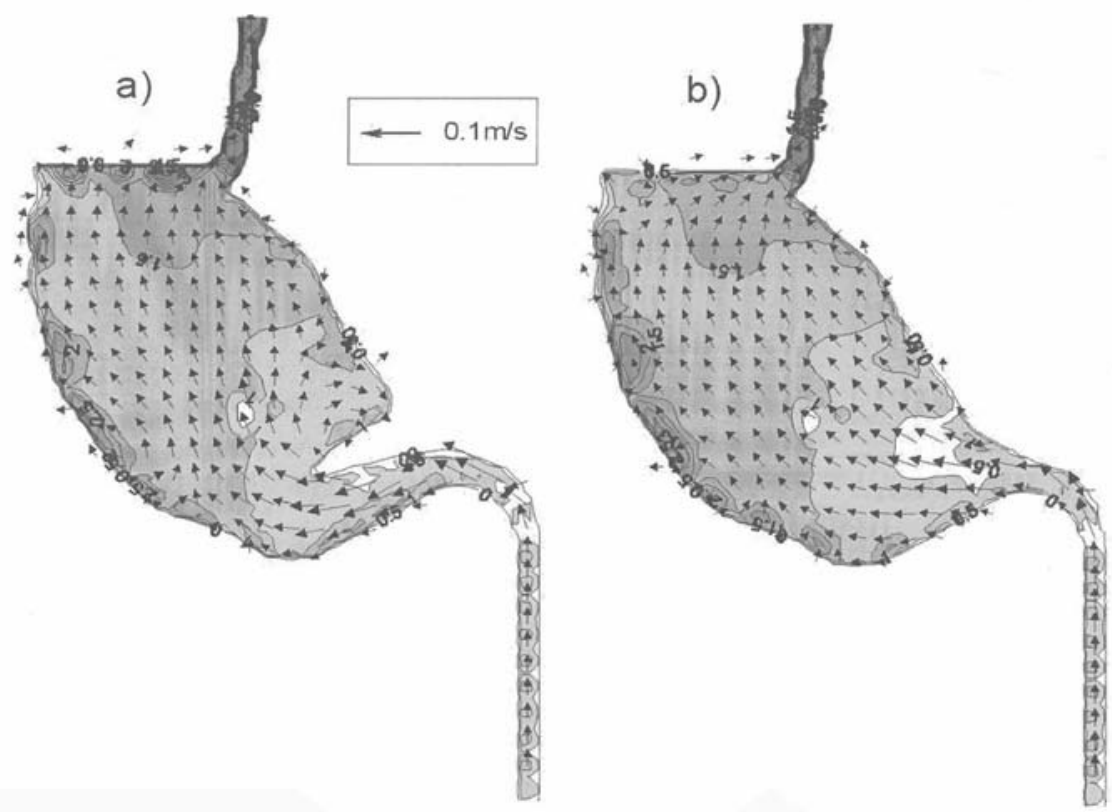

Figure 2. Numerical simulation of the vertically averaged velocity field in Alhama de Granada Reservoir. Vector in the box depicts velocity module scale a) March 2001. b) May 2001. Campos de velocidad (promediada en la vertical) simulados para el embalse de Alhama de Granada. El vector en el recuadro superior representa la escala para los módulos de velocidad. a) Marzo 2001. b) Mayo 2001. 
correspond to March 2001, under low water level; diversion tunnel working $\left(0.2 \mathrm{~m}^{3} / \mathrm{s}\right.$ approx.) and sediment bar emerged. The second scenario corresponds to May 2001 (Fig. 2b), just when the diversion tunnel was closed; the discharge took place over the spillway crest; a corresponding higher water level was measured and the sediment bar became submerged. No significant wind action was observed in any case, so we assumed the hydraulic management to be the main responsible for water flow.
Under both conditions, there is a continuous water flux through the reservoir, consisting of an inflow from the river Alhama, and an outflow through the diversion tunnel or over the spillway crest, depending on the hydraulic conditions.

Figures $3 \mathrm{a}$ and $3 \mathrm{~b}$ show the phytoplankton spatial distribution at surface and bottom layers as observed in March. Please note that the shoreline differences observed in this figure with respect to the natural shore-line shown in figure1, are consequence of the statistical method for
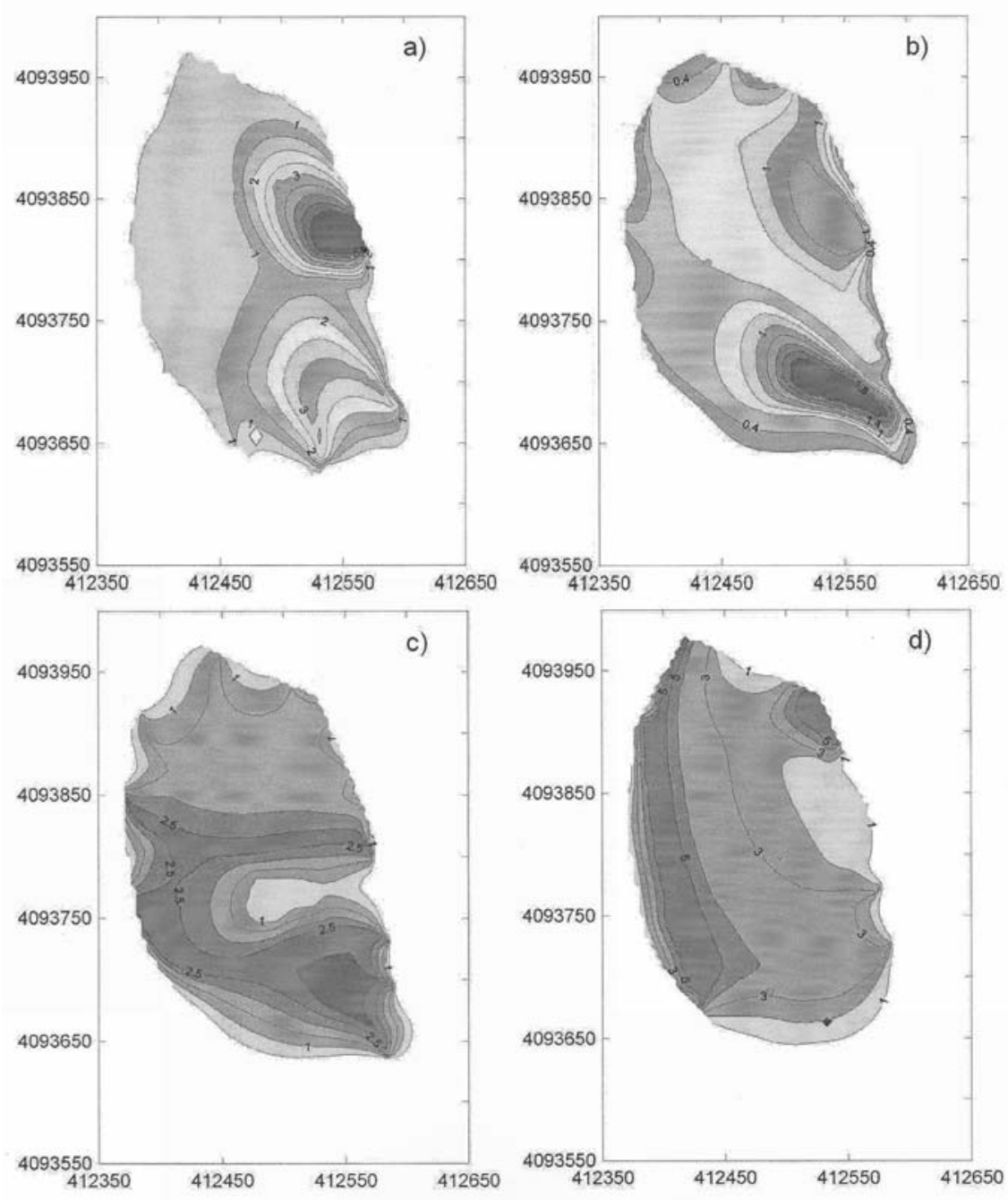

Figure 3. Chlorophyll- $a\left(\mathrm{mg} / \mathrm{m}^{3}\right)$ spatial distribution in Alhama de Granada Reservoir. a) March 2001. Bottom. b) March 2001. Surface. c) May 2001. Bottom. d) May 2001. Surface. Distribución espacial de la Clorofila-a ( $\left.\mathrm{mg} / \mathrm{m}^{3}\right)$ en el embalse de Alhama de Granada. a) Marzo 2001, fondo. b) Marzo 2001, superficie. c) Mayo 2001, fondo. d) Mayo 2001, superficie. 
map-building. In the first case, the comparative analysis of the mean velocity field (Fig. 2a) and the Chl- $a$ spatial distribution (Fig. 3a and 3b), shows a considerable influence of the circulation downstream the sediment bar, just generating a phytoplankton accumulation extending all over that region. This algal patch (mainly composed of the Cyanophyceae Oscillatoria sp.) became more concentrated towards the bottom, where it reaches its maximum biomass. There was also another phytoplankton patch in the near-shore region close to the inlet of the diversion tunnel, as a consequence of water flow advective transport.

Hydrodynamics is quite different in the case of high water level (Fig. 2b), when the sediment bar remains submerged and there is an overflow through the spillway; this can be observed in figures $3 \mathrm{c}$ and $3 \mathrm{~d}$, corresponding to May. Here, the comparative analysis of the velocity field (Fig. 2b) and the phytoplankton spatial distribution, shows differences from surface to bottom. In this situation, the flow dynamics prevents any algal advective accumulation at surface around the sediment bar (Fig. 3d).

By contrast, the sediment bar seems to continue affecting the water currents close to the bottom of the reservoir, generating a deep circular movement and a phytoplankton patch (again dominated by Oscillatoria sp.) similar to that existing when the sediment bar is emerged (Fig. 3c). Unfortunately, this circular current can not be derived from the numerical simulation, since the shallow water approach for equations (1) and (2) implies a vertical-averaged velocity profile; Because of that, it ought to be estimated from field observations.

Water movements generate slightly higher velocities along the East margin of the reservoir $(0.06 \mathrm{~m} / \mathrm{s}$ mean velocity) than those along the West one $(0.03 \mathrm{~m} / \mathrm{s}$ mean velocity), hence justifying the higher phytoplankton biomass along the West margin, as low velocities improve the growing conditions for some turbulence-sensitive algal groups, e.g. Cyanophyceae. By contrast, high velocities (and the associated turbulence) prevent the development of well-structured phytoplankton patches along the East shore of the reservoir. There was also a small phytoplankton patch loca- ted near the entrance of the diversion tunnel (by this time, closed), as this zone was protected from the approaching current towards the spillway.

Upstream of the spillway section lower Chl- $a$ concentration were found, as it could be expected from the higher approaching velocities, yielding more restrictive conditions for growth of certain algal groups to grow (e.g. Cyanophyceae).

In summary, our results show that in smallsize reservoirs phytoplankton spatial distribution responds mainly to the advective velocity field, in agreement with those found by George \& Edwards (1976) in a small shallow reservoir.

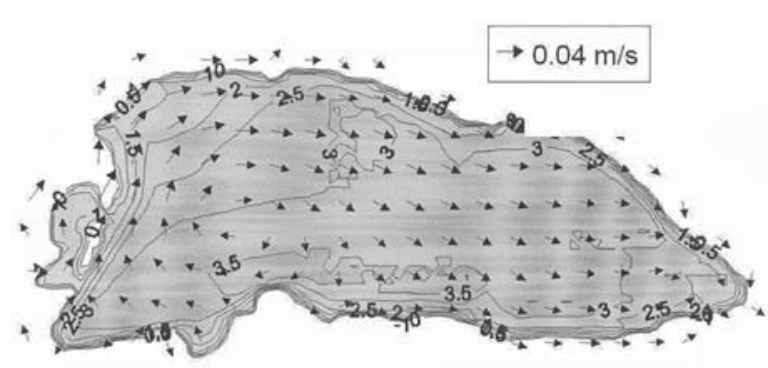

Figure 4. Numerical simulation on the velocity field $(\mathrm{m} / \mathrm{s})$ in Laguna Nueva. April 2001. Vector in the box depicts velocity module scale Simulación numérica del campo de velocidades $(\mathrm{m} / \mathrm{s})$ en la Laguna Nueva. Abril 2001. El vector en el recuadro superior representa la escala para los módulos de velocidad.

\section{Ecohydrodynamics of Laguna Nueva}

Because of the hydrological features of this system (lack of surface inlets and outlets; almost all the water supply to the system coming from underground sources), the prevailing winds (Southwest direction and a mean velocity of 5 $\mathrm{m} / \mathrm{s}$ at $2 \mathrm{~m}$ over the water surface) constitute the main factor inducing the water movements. In combination with lake morphometry, wind is responsible for the main hydrodynamic pattern and, as a consequence, it also influences the phytoplankton spatial dynamics.

Figure 4 shows the simulated mean velocity field at surface level generated by wind stress in Laguna Nueva, validated with field observations. An anticyclone gyre induced in the central zone of the lagoon must be highlighted, some- 
thing common in the hydrodynamic behaviour of shallow lakes and reservoirs induced by the interaction between water currents and the basin morphomentry (Fort et al., 1996), and relevant as a main factor conditioning phytoplankton spatial distribution (Ganf, 1974; Ishikawa et al., 2002).

Phytoplankton spatial distribution in the lagoon seems to be a direct consequence of such hydrodynamic pattern. In fact, it is possible to detect a phytoplankton patch in the area influenced by the gyre. The patch is larger at the surface, where the lowest Chl- $a$ concentration was found. However, Chl- $a$ increases with depth, while the horizontal dimension of the patch decreases. Bacilliarophyceae and some Cyanophyceae (Oscillatoria sp. and Pseudoanabaena sp.) were among the most important algal groups present in the patch.

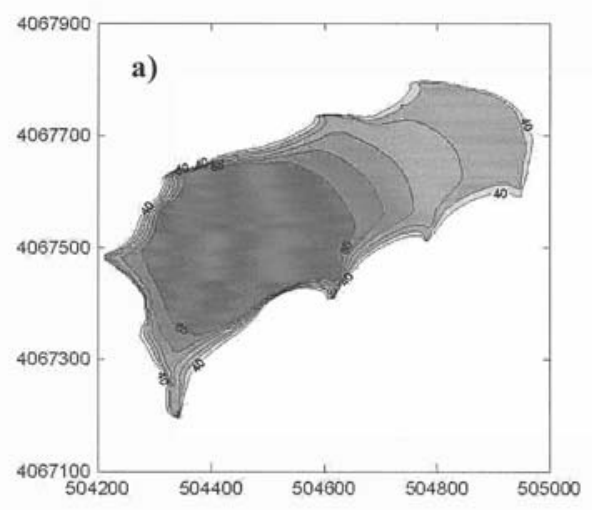

Figure 5 depicts the Chl- $a$ distribution at surface, middle depth and bottom, corresponding to the modelled hydrodynamic scenario (April 2001). Analysis of the phytoplankton spatial distribution plots at different depths outlines the aforementioned situation, arising from the induced effect of the central gyre. As pointed before, the statistical map-building method causes some differences with respect to the natural shore-line contour.

On the other hand, the hydrodynamics study shows a main flow downstream the gyre, directed towards the Northeast shore of the system. As a consequence, there is an increase in Chl- $a$ concentration at the Northeast end of the lagoon, at middle depth and bottom layers, accompanied by a decrease at surface. This phytoplankton distribution pattern could be induced by a downwelling

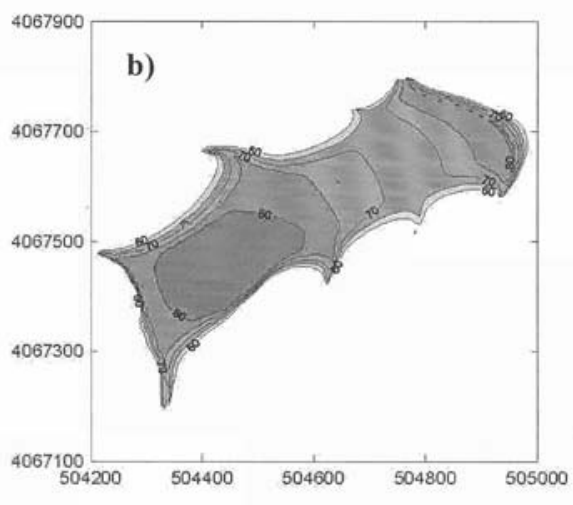

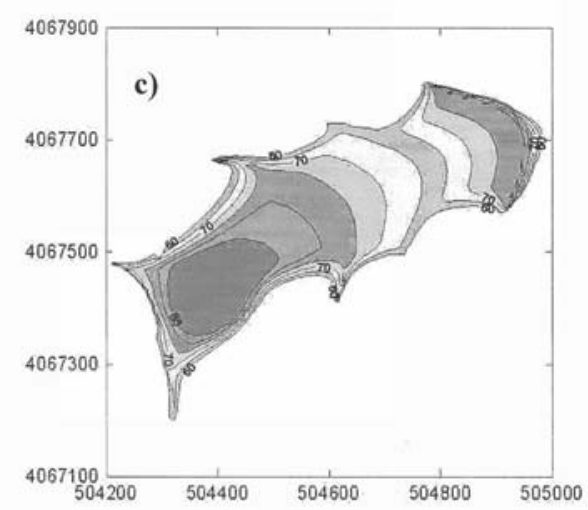

Figure 5. Chlorophyll- $a\left(\mathrm{mg} / \mathrm{m}^{3}\right)$ spatial distribution in Laguna Nueva. April 2001. a) Surface layer. b) Middle depth. c) Bottom layer. Distribución espacial de la Clorofila-a $\left(\mathrm{mg} / \mathrm{m}^{3}\right)$ en la Laguna Nueva. Abril 2001. a) Superficie. b) Media profundidad. c) sobre elfondo. 


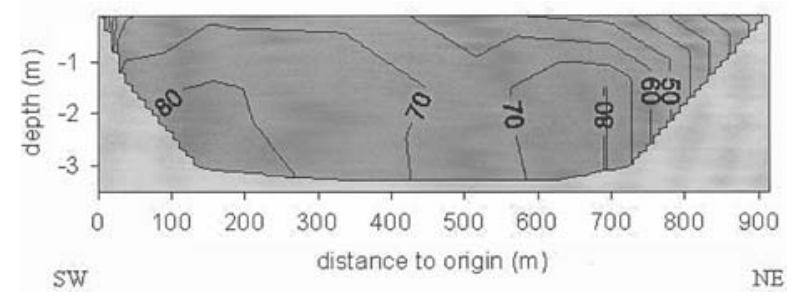

Figure 6. Vertical distribution of Chlorophyll- $a\left(\mathrm{mg} / \mathrm{m}^{3}\right)$ in Laguna Nueva. April 2001. Distribución vertical de la Clorofila-a $\left(\mathrm{mg} / \mathrm{m}^{3}\right)$ en la Laguna Nueva. Abril 2001.

circulation contained in the vertical axis, which could transport algae from surface to deeper layers.

A vertical Chl- $a$ distribution plot (Fig. 6) clearly shows the hydrodynamics-induced phytoplankton patchiness above mentioned and the two main algal patches described, corresponding to the increase in Chl- $a$ concentration at middle depth and at the bottom in the NE margin and that described inside the area located at 200-400 $\mathrm{m}$ from the origin, developed under the influence of the anticyclone circular current.

Again, our results are coherent with George's (1981, 1993) suggestion of the mechanisms involved in the formation and destruction of plankton patches in freshwater systems, and their spatial and temporal scales; our results come to demonstrate that the phytoplankton spatial distribution in the lagoon is clearly governed by advective transport.

Whole-lake experiments performed to improve the understanding of the role of hydrodynamics on the control of some harmful phytoplankton groups, especially Cyanobacteria (Steinberg \& Gruhl, 1992), lead to the conclusion that water motions, turbulence and mixing constitute the main agents responsible of phytoplankton spatial and temporal dynamics. According to Imberger (1994), studies and experiments on the physical-biological coupling in lakes and reservoirs are among the most important key research areas for the future. He also considers numerical modelling of physical processes as a useful and necessary tool for the adequate description of transport in aquatic systems.

In this study there is an attemp to go on in such a way, showing the influence of water movements on the spatial dynamics of microalgae and, consequently, on the water quality of the system. This knowledge becomes especially important in the case of reservoirs, where hydrodynamic is highly controlled by hydraulic management and plays a main role in the control of non-desirable phytoplankton patchiness.

\section{CONCLUSIONS}

For the two ecosystems studied, phytoplankton spatial distribution patterns were described, and its coupling with hydrodynamics under different hydraulic conditions was discussed. As a first conclusion, hydrodynamics induced by external factors (wind action, inlet/outlet discharge balance) highly influences the microalgae spatial heterogeneity. Water currents are strongly conditioned by bed topography and contour morphology, leading to a notorious spatial heterogeneity in physical features such as circular movements and different velocity patterns varying with location in the horizontal and/or vertical axis.

For the purpose of this study both field data and numerical simulation results were applied, obtaining a complete description of the physicalbiological coupling in the systems.

This work contains the first results of a more extended project, with the final aim of developing a management model for aquatic ecosystems, in which all possible agents influencing water quality could be taken into account. In this context, it will be feasible to predict the development of phytoplankton patchiness in certain zones with specific hydrodynamic conditions, so ensuring the control over water quality status; controlling the hydrodynamics of the system (i.e. managing the operative regime of the outlet works compatible with the upstream and downstream requirements, selectively withdrawing the water or using appropriate water mixing devices) will lead to a more precise control of the algal populations, which in some cases (as happens with Cyanophyceae and some Dinoflagellates) could work against water quality. This hydrodynamics control is especially suitable and useful in reservoirs, and could optimise water quality, finally resulting in considerable economic savings. 


\section{ACKNOWLEDGEMENTS}

The study on the Alhama de Granada Reservoir was supported by the Guadalquivir River Water Authority. The study on the Laguna Nueva de la Albufera de Adra was financed by the projects EU-LIFE B4-3200/98/458 and CICYT HID 990836. Authors wish to thank the aforementioned entities; without their support the present work could not have been finished.

\section{REFERENCES}

BEUTLER, M., K. H. WILTSHIRE, B. MEYER, C. MOLDAENKE, C. LÜRING, M. MEYERHÖFER, U.P. HANSEN \& H. DAU. 2002. A fluorometric method for the differentiation of algal populations in vivo and in situ. Photosynthesis Research, 72: 39-53.

DE VICENTE, I., L. SERRANO, V. AMORES, V. CLAVERO \& L.CRUZ-PIZARRO. 2003. Sediment phosphate fractionation and interstitial water phosphate concentration in two coastal lagoons (Albuferas de Adra, SE Spain). Hydrobiologia, 492: 95-105.

DUBNYAK, S. \& V. TIMCHENKO. 2000. Ecological role of hydrodynamic processes in the Dnipier reservoirs. Ecological Engineering, 16: 181-188.

EL MABROUKI, K., A. MOÑINO, J. BECERRA, M.C. MOLINA, I. DE VICENTE, E. MORENOOSTOS, V. AMORES, V. CLAVERO \& L. CRUZPIZARRO. 2001. Características limnológicas del embalse de Alhama (Granada). In: V Simposio sobre el agua en Andalucía. Vol I. A. Pulido Bosch, P.A. Pulido Leboeuf \& A. Vallejos Izquierdo (eds.). Almería. 385-396.

FORT, J., J. POCH \& E. ROGET. 1996. Hydrodynamics of shallow lakes subject to wind: gyres and geometry. Applied Mathematics and Mechanics, 76: 147-148.

GANF, G. G. 1974. Phytoplankton biomass and distribution in a shallow, eutrophic lake (Lake George, Uganda). Oecologia, 16: 9-29.

GEORGE D. G. 1981. Zooplankton patchiness. Reports of the Freshwater Biology Association, 49: 32-43.

GEORGE, D. G. 1993. Physical and chemical scales of pattern in freshwater lakes and reservoirs. The Science of the Total Environment, 135: 1-15.
GEORGE, D. G. \& S. L. EDWARDS. 1976. The effect of wind on the distribution of chlorophyll-a and crustacean plankton in a shallow eutrophic reservoir. Journal of Applied Ecology, 13: 667-690.

GEORGE, D. G. \& S. I. HEANEY.1978. Factors influencing the spatial distribution of phytoplankton in a small productive lake. Journal of Ecology, 66: 133-155.

GEORGE, D. G. \& L. CRUZ-PIZARRO. 1994. Factors influencing the spatial distribution of phytoplankton in embalse de Iznajar (Andalucía, Spain). First International Airborne Remote Sensing Conference and Exhibition. Vol III: 9-19Strasbourgh, France.

HARRIS, G. P. \& R. H. SMITH.1977. Observations of small scale spatial patterns of phytoplankton populations. Limnol. Oceanogr., 25: 1093-1103.

HEANEY, S. I. 1976. Temporal and spatial dsitribution of the dinoflagellate Ceratium hirundinella O.F. Müller within a small productive lake. Freshwat. Biol., 6: 531-542.

IMBERGER, J. 1994. Transport processes in lakes: A review. In: Limnology now, a paradigm of planetary problems. R.Margalef (ed.).: 99-113. Elsevier. Amsterdam.

ISHIKAWA, K.; M. KUMAGAI, W. F. V. SHIGEO TSUJIMURA, H. NAKAHARA. 2002. Transport and accumulation of bloom-forming cyanobacteria in a large, mid-latitude lake: the gyre-Microcystis hypothesis. Limnology, 3: 87-96.

JEFFREY, S. W. \& G. F. HUMPHREY. 1975. New spectrophotometric equations for determining chlorophylls a, b, c1 and c2 in higher plants, algae and natural phytoplankton. Biochemistry and Physiology, 167: 191-194.

KUNDU, P. K. 1990. Fluid mechanics. Academic Press. San Diego. 638 pp.

LEBOULANGER, C., U. DORIGO, S. JACQUET, B. LEBERRE, G. PAOLINI \& J. HUMBERT. 2002. Application of a submersible spectrofluorometer for rapid monitoring of freshwater cyanobacterial blooms: a case study. Aquat. Microb. Ecol., 30: 83-89.

LEGENDRE, L. \& S. DEMERS. 1984. Towards dynamic biological oceanography and limnology. Can. J. Fish. Aquat. Sci., 41: 2-19.

LEGENDRE, P. \& M. FORTIN. 1989. Spatial Pattern and ecological analysis. Vegetatio, 80: 107-138.

MORENO-OSTOS, E. 2002. Patrones de distribución espacial del fitoplancton en sistemas 
acuáticos. Proyecto de Investigación. Universidad de Granada. 66 pp.

MORENO-OSTOS, E. 2004. Spatial dynamics of phytoplankton in El Gergal reservoir (Seville, Spain). Ph. D. Thesis. Universidad de Granada. $354 \mathrm{pp}$.

PETTERSON, K., L. FORSELL \& T. HASSELROT. 1995. Horizontal distribution patterns during a cyanobacterial bloom. Wat. Sci. Tech., 4: 139-142.

REYNOLDS, C. S., 1984. The ecology of freshwater phytoplankton. Ed. Cambridge University Press. Cambridge. 384 pp.

RODI, W. 1980. Turbulence models and their application in hydraulics. A state of the art review. Institut für Hydromechanik, University of Karlsruhe, Germany. 104 pp.

SALONEN, K., J.SARVALA, M. JÄRVINEN, V. LANGENBERG, M. NUOTTAJÄRVI, K. VUORIO \& D.B.R CHITAMWEBWA. 1999. Phytoplankton in Lake Tanganika-vertical and horizontal distribution of in vivo fluorescence. Hydrobio- logia, 407: 89-103.

STEELE, J. H. 1974. Spatial heterogeneity and population stability. Nature, 248: 83.

STEINBERG, C. E. W. \& E. GRUHL. 1992. Physical measures to inhibit planktonic cyanobacteria. In: Eutrophication: Reseach and application to water supply. D.W. Sutcliffe \& J.G. Jones (eds.): 163-184. Freshwater Biological Association. Ambleside.

STRUTTON, P. G., J. G. MITCHELL, J. F. PARSLOW \& R. M.GREENE.1997. Phytoplankton patchiness: quantifying the biological contribution using Fast Repetition Rate Fluorimetry. J. Plankton. Res., 19: 1265-1274.

VAN RIJN, L. 1990. Principles of Fluid Flow and Surface Waves in Rivers, Estuaries, Seas and Oceans. Aqua Publications. Amsterdam. The Netherlands. $335 \mathrm{pp}$.

VERHAGEN, J. H. G. 1994. Modelling phytoplankton patchiness under the influence of wind-driven currents in lakes. Limnol. Oceanogr., 39: 1551-1565. 